\title{
A talajok aggregátum-stabilitásának vizsgálati lehetőségei I. Makroaggregátum-stabilitás
}

\author{
1*LABAncz Viktória, ${ }^{2}$ BARna Gyöngyi, ${ }^{1}$ SzEgi Tamás, ${ }^{2,3}$ MAKÓ András \\ ${ }^{1}$ MATE, Szent István Campus, Környezettudományi Intézet, Talajtani Tanszék, \\ Gödöllö; ${ }^{2}$ ATK TAKI, Talajfizikai és Vízgazdálkodási Osztály, Budapest; ${ }^{3}$ MATE, \\ Georgikon Campus, Környezettudományi Intézet, Környezeti Fenntarthatóság Tanszék, \\ Keszthely
}

(Beérkezett: 2021.03.12.; Elfogadva: 2021.05.14.)

\section{Bevezetés}

A talajban az egyedi szemcsék, azaz az elsődleges szilárd alkotó elemek (ásványi komponensek) önmagukban csak ritkán fordulnak elő. Különféle elrendeződésekben, változatos alakú-, méretű-, eltérő szerveződésủ aggregátumok formájában vannak jelen, amelyek egyedi elrendeződése alakítja ki a talaj szerkezetét, létrehozva ezzel a víz és levegő által elfoglalható pórustereket (MARSHALl \& HOLMES, 1979). A talajszerkezet tulajdonságait tekintve rendkívül összetett, mivel az alkotórészek mérete, alakja és kémiai összetétele különböző, valamint az egyedi talajszemcséket összekötő, aggregátumokat kialakító mechanizmusok is - a talajokban lejátszódó folyamatoktól függően - igen változatosak lehetnek. Az aggregátumok alakja mérete, térbeli elrendeződése határozza meg a pórusok méretét és kapcsolatrendszerét, befolyásolva ezzel számos anyagtranszportot (hő, gáz, víz és oldott tápanyagok szállítása, valamint raktározása), végső soron számos fizikai, kémiai és biológiai folyamatot (LEHRSCH \& JOLLEY, 1992; PENG et al., 2015).

A talaj szerkezete leírható aggregátumainak alakja, mérete és stabilitása szempontjából is. Amennyiben alak szerint vizsgáljuk az aggregátumokat, morfológiai talajszerkezetről beszélünk. Az aggregátumok méret szerinti eloszlását másként agronómiai talajszerkezetnek is nevezik, és általában szitasorokkal határozzák meg (KEMPER \& ROSENAU, 1986; STEFANOVITS et al., 1999).

Egyszerüsített mérettartományi besorolásukat tekintve, a nemzetközi szakirodalom a $250 \mu \mathrm{m}$-nél nagyobb aggregátumokat makro-, a $250 \mu \mathrm{m}$-nél kisebbeket mikroaggregátum kategóriába sorolja. A makroaggregátumok tovább oszthatók még a 250-2000 $\mu$ m közti „kis makroaggregátumokra” és a $2000 \mu \mathrm{m}$ feletti „nagy makroaggregátumokra”, bár az egyes irodalmi források eltérő mérethatárokat is közölhetnek (TISDALL \& OADES, 1982; SIX et al., 1999). Hasonló a helyzet a

*Levelezö szerzö: LABANCZ VIKTÓRIA, Magyar Agrár- és Élettudományi Egyetem, Gödöllői Campus, Környezettudományi Intézet, Talajtani Tanszék, 2100 Gödöllő, Páter Károly u. 1.

E-mail: viktoria.labancz.91@gmail.com 
mikroaggregátumoknál, ahol egyes szerzők a 20-250 $\mu \mathrm{m}$ közti, mások az 50-250 $\mu \mathrm{m}$, vagy a 63-250 $\mu \mathrm{m}$ közötti frakciót sorolják ebbe a méretkategóriába (JOHN et al., 2005; HBIRKOU et al., 2011; LOBE et al., 2011). A mikroaggregátumok is további frakciókra oszthatók: például a 2-20 $\mu \mathrm{m}$ közötti agyag flokkulátumok és iszap részecskék összekapcsolódásával kialakult aggregátumokat iszap vagy klaszter (cluster) frakciónak hívják, a $2 \mu \mathrm{m}$ alatti mérettartományt agyag flokkulátumok néven különítik el (OADES \& WATERS, 1991; JASTROW et al., 1996; TOTSCHE et al., 2018). A felsoroltakon kívül számos egyéb méretbeli felosztás létezik. Hazai viszonylatban elsők között BALLENEGGER és DI GLÉRIA (1962), később STEFANOVITS és munkatársai (1999) határozták meg eltérő tulajdonságuk alapján és saját tapasztalataik szerint az egyes frakciók mérethatárait (finom mikroaggregátumok: $\quad<10 \mu \mathrm{m}$; mikroaggregátumok: $\quad 10-250 \mu \mathrm{m}$; kis makroaggregátumok: 250-1000 $\mu \mathrm{m}$; közepes makroaggregátumok: 1000-3000 $\mu \mathrm{m}$; nagy makroaggregátumok: $3000-10000 \mu \mathrm{m}$; kisebb megaaggregátumok: $10000-20000 \mu \mathrm{m}$ és nagyobb megaaggregátumok: $>20000 \mu \mathrm{m})$.

Az aggregátumok képződését leíró, jelenleg leginkább elfogadott hierarchikus képződési modell különböző kötési mechanizmusokat feltételez az egyes mérettartományok esetében, valamint a kötőanyagok eltérő stabilizáló hatását a talajmátrixon belül (EMERSON \& GREENLAND, 1990; MURRAY \& QUIRK, 1990; OADES, 1990; TISDALL, 1996).

Jelen tanulmányunkban a makroaggregátumok stabilitásának meghatározására szolgáló legfontosabb módszereket, illetve a stabilitást kifejező indexeket összegezzük.

\section{Az aggregátumok stabilitása}

A talaj szerkezete jellemezhető az aggregátumok stabilitásával is. A stabilitás a különbözö degradációs hatásokkal (például a defláció vagy a víz eróziós tevékenysége, továbbá a talajművelés mechanikai romboló hatása stb.) szembeni ellenállás mértékét fejezi ki az idő függvényében. Segítségével jellemezhető egy adott talaj víz- vagy szélerózióra való hajlama is. A talajaggregátumokra vonatkozó különböző stabilitási mutatók felhasználhatóak a különféle mezőgazdasági beavatkozások, így például a talajmüvelés erodáló hatásainak becslésére, vagy elörejelzésére (VÁrALLYAY, 1993; LAL \& SHUKLA, 2004; NIMMO, 2004; HUISZ, 2007).

A talajok aggregátum-stabilitását számos tényező befolyásolhatja (1. táblázat). BALLENEGGER (1933) szerint a két legfontosabb ezek közül a humusz és az agyagszemcsék jelenléte. KAY (1997) és AMÉZKETA (1999) a stabilitást befolyásoló tényezőket két nagy csoportra osztotta: a talaj jellemzőiből adódó belső tényezőkre (pl. ásványi és szerves eredetü cementáló anyagok), valamint a talajtól független külső tényezőkre (pl. környezeti, mezőgazdasági hatások).

Általánosságban a mikroaggregátumokat túlnyomórészt szerves-ásványi komplexek (ún. organominerális komplexek) stabilizálják, melyek viszonylag stabilak, és azokat a talaj szervesanyag tartalmának a földhasználat és a müvelés eredményeként bekövetkező változásai sem bontják meg könnyen. Különbséget kell 
viszont tenni azonban a $20 \mu \mathrm{m}$-nél kisebb, illetve nagyobb mikroaggregátumok között. A $20 \mu \mathrm{m}$-nél kisebb aggregátumokat van der Waals-erök és elektrosztatikus kölcsönhatások stabilizálják, és föként az ionok (elsősorban kationok) minősége felelős az aggregátumok kialakulásáért, tartósságáért. A nagy mennyiségü kicserélhető nátrium jelenléte pl. kedvezőtlen hatású, mivel az elemi részecskéket diszpergálja, míg a kicserélhető $\mathrm{Ca}^{2+}$ ezzel szemben talajszerkezet stabilizáló hatású (DVORACSEK, 1952; BARZEGAR et al., 1994). A $20 \mu \mathrm{m}$-nél nagyobb mikroaggregátumok esetében a stabilizáló, cementáló anyagok a fentiekben említett szerves-ásványi komplexek (szerves vegyületek; Fe-, Mn-, Al- és Si-oxi-hidroxidok, Al-szilikátok; karbonátok) (OADES \& WATERS, 1991), ahol a szervesanyag túlnyomórészt a mikroaggregátumok felületein koncentrálódik (AMELUNG et al., 2002, TOTSCHE et al., 2018).

\section{1. táblázat}

A különböző méretü aggregátumokat létrehozó folyamatok és anyagok

(Források: OAdES \& WATERS, 1991, AMÉZKETA, 1999, LAL \& SHUKLA, 2004, NiMMO, 2004, TOTSCHE et al., 2018)

\begin{tabular}{|c|c|l|}
\hline $\begin{array}{c}\text { Mérettartomány } \\
\text { neve }\end{array}$ & Mérete & Stabilitás kialakító anyagok és mechanizmusok \\
\hline $\begin{array}{c}\text { Agyag } \\
\text { flokkulátumok }\end{array}$ & $2 \mu \mathrm{m}>$ & $\begin{array}{l}\text { agyagásványok összekapcsolódása intermolekuláris } \\
\text { kölcsönhatásokkal (van der Waals, elektrosztatikus) }\end{array}$ \\
\hline $\begin{array}{c}\text { Agyag } \\
\text { flokkulátumok } \\
\text { +iszap frakció }\end{array}$ & $\begin{array}{c}2-20(50, \\
63) \mu \mathrm{m}\end{array}$ & $\begin{array}{l}\text { agyag-iszap részecskék összekapcsolódása kolloid } \\
\text { méretủ anyagokkal: vas-alumínium oxidok, } \\
\text { szervesanyag, mikroorganizmusok tevékenységei }\end{array}$ \\
\hline $\begin{array}{c}\text { Mikro- } \\
\text { aggregátumok }\end{array}$ & $\begin{array}{c}20(50,63)- \\
250 \mu \mathrm{m}\end{array}$ & $\begin{array}{l}\text { szerves-ásványi komplexek, baktériumok } \\
\text { élettevékenysége }\end{array}$ \\
\hline $\begin{array}{c}\text { Makro- } \\
\text { aggregátumok }\end{array}$ & $250 \mu \mathrm{m}<$ & $\begin{array}{l}\text { talajlakó gombák élettevékenysége (pl. gombafonalak), } \\
\text { növényi gyökerek és növényi jelenlét, szervesanyagok, } \\
\text { nedvesedési-száradási- és fagyási-olvadási ciklusok } \\
\text { /művelés hatásai - pl. trágya, komposzt/ }\end{array}$ \\
\hline
\end{tabular}

A makroaggregátumok stabilitása sokkal inkább függ a talaj „élő és holt” szervesanyagaitól, éppen ezért a stabil makroaggregátumok aránya párhuzamosan változik a talaj szervesanyag-tartalmának alakulásával (LAL \& SHUKLA, 2004). Biológiai szempontból a talajlakó gombáknak, baktériumoknak, illetve az egyéb mikrobiális eredetü metabolikus anyagoknak (pl. glomalin) van igen jelentős szerepük az aggregátumokon belüli kötésének kialakításában (LAL \& SHUKLA, 2004; NIMMO, 2004; DUNAI \& TÓTH, 2015; TOTSCHE et al., 2018). Aggregátumok gyakran a növényi gyökérzet körül is kialakulnak, a gyökérváladék serkenti a mikrobiológiai aktivitást. A makroaggregátumok képződésében jelentős szerepet játszhatnak a talajfauna tagjai (pl. a földigiliszták, termeszek, hangyák) (COLEMAN et al., 2018).

A szervesanyag az aggregátumok felületén hidrofób bevonatot képezhet, mely csökkentheti a nedvesítés sebességét, mérsékelve ezáltal a szétiszapolódás lehetőségét (SULLIVAN, 1990). A szervesanyag stabilizáló hatása igen könnyen 
sérülhet, ezek a degradációs folyamatok elsősorban a makroaggregátumokat érintik (SULLIVAN, 1990; BLACKMAN, 1992).

A hosszútávú talajművelés csökkenő humuszmennyiséghez vezet, ami szignifikáns korrelációt mutat a makro- aggregátum-stabilitás csökkenésével is (BARTLOVÁ et al., 2015). A termesztett növények is befolyásolhatják a makroaggregátum-stabilitást: pl. az árpa és lucerna kultúrák után nagyobb stabilitás mérhető, mint kukorica monokultúrában (BALDOCK \& KAY, 1987).

\section{A talajok aggregátum-stabilitásának vizsgálati módszerei}

Számos módszer létezik a talajok aggregátum-stabilitásának mérésére. A módszerek nagy száma a különböző eredetủ degradáló hatást modellező eljárásokkal, valamint a többféle stabilitási skálával, mutatóval, illetve az eltérő módszertani lehetőségekkel magyarázható (AMÉZKETA, 1999). A talaj aggregátum stabilitásának mérési módszerei szimulálják az aggregátumok lebomlásának természetes folyamatát. Az aggregátum szétesésnek LE BisSONNAIS (1996) szerint négy fö folyamat-típusa különíthető el: (1) a hirtelen nedvesítés során az aggregátumokban bezárt levegő aggregátumokat szétrobbantó hatása; (2) a duzzadás és zsugorodás következtében fellépő aggregátum szétesés; (3) továbbá a mechanikai hatásra történő aggregátum szétesés; (4) valamint az aggregátumok diszpergálódása fizikai-kémiai, valamint ozmotikus stressz hatására. A mérési módszerek kiválasztása és az eredmények értékelése mindig a mérés céljától függ (ROHOŠKOVÁ \& VALLA, 2004). Lényeges, hogy az alkalmazott módszerek könnyen elvégezhetők és reprodukálhatók legyenek. Számos, a vizsgált talajra vonatkozó feltételt is figyelembe kell venniük, továbbá alkalmazhatónak kell lenniük a legtöbb talajtípusra (LE BISSONNAIS, 1996). Értelmezési és összehasonlíthatósági problémákat vethet fel, hogy egy adott módszer mely típusú aggregátumstabilitás meghatározására hivatott, ezen problémák sokszor szóhasználati különbségekből fakadnak. Míg például a makroaggregátum-stabilitás meghatározást a legtöbb szakirodalom egyszerủen aggregátumstabilitás vizsgálat szavakkal fejezi ki, addig a mikroaggregátumok esetében sokszor a diszperziós tesztek kifejezést használják (AMÉZKETA, 1999).

A mérések eredményeit, azok összehasonlíthatóságát befolyásolhatják a mintavétel körülményei, a vizsgált minta jellemzői, az adott mintára megválasztott kezelés (pl. vízzel szembeni stabilitás esetén az eltérő előnedvesítési eljárások), vizes közeg esetén az eltérő vízkémiai paraméterek (pl. elektromos vezetőképesség (EC), nátrium adszopciós arány (SAR)), a vizes közeg hömérséklete (BALLENEGGER, 1953; SEKIGUCHI et al., 2021), a különböző mérési módszerek, illetve az eredmény közlésének módja (stabilitási mutatók).

A makroaggregátumok vizsgálatára számos módszer létezik, az egyszerübben kivitelezhető és reprodukálható eljárásoktól a bonyolultabb, műszert igénylő módszerekig. A makroaggregátum-stabilitási vizsgálatok közül a legegyszerübbek a vizuális értékelésen alapuló módszerek, mint például a Sekera-féle eljárás (SEKERA \& BRUNNER, 1943). A mérési módszerek közül a vizes közegben végzett eljárások, főként a nedves szitás (wet sieving) vizsgálatok különböző változatait alkalmazzák széleskörüen (YODER, 1936; KEMPER \& ROSENAU, 1986; LE BISSONNAIS, 1996). 
A talajok aggregátum-stabilitásának vizsgálati lehetőségei I. Makroaggregátum-stabilitás 91

Ennek oka, hogy mezőgazdasági termőterületek többségén a víz romboló hatása a legjelentősebb; az aggregátumok hirtelen, gyors vagy túlzott mértékủ nedvesedése nagymértékben szétiszapolhatja a talaj szerkezeti elemeit. Éppen ezért a talajszerkezet minősége elsősorban az aggregátumok vízállóságának függvénye. Előnyük, hogy azonos módszerrel előkészített, azonos mérési körülmények között (szita átméröje, áztatás ideje és a mozgatás amplitúdója) mért minták esetében egymással összehasonlítható aggregátum-stabilitási mutatót kaphatunk. A talajművelés romboló és a szélerózió hatásainak tanulmányozására ritkábban alkalmazott módszer az aggregátumok száraz körülmények közt történő méreteloszlásának meghatározása szitálással (dry sieving) (KEMPER \& ROSEANU, 1986). Az aggregátumok stabilitását ezen kívül vizsgálhatják még esőztető módszerrel, az esőcsepp erodáló hatásának megállapítására, melyet az aggregátum romboláshoz szükséges kinetikus energia nagysága alapján értékelnek (MCCALLA, 1944; BRUCE-OKINE \& LAL, 1975; LAL \& SHUKLA, 2004).

A mikroaggregátumok stabilitás mérésére összpontosító módszerek alapvetően a talaj agyag- és/vagy iszapméretü részecskéinek számszerüsítésén alapulnak. Ezen mérések esetében a talaj agyag- és/vagy iszapfrakciójának diszpergálódási mértékét vizsgálják, alapul véve azt az elméletet, hogy minél stabilabbak egy adott talaj mikroaggregátumai, annál kevesebb agyag (és/vagy iszap) diszpergálódik vizes közegben. Míg kezdetben az idö- és munkaigényesebb ülepítéses módszereket alkalmazták a talajok mikroaggregátum-stabilitásának meghatározására (pl. VAGELER, 1932; KACHINSKY, 1965), az 1980-as években elterjedtek a gyorsabb és könnyebben reprodukálható lézerdiffraktometriás módszerek (igaz, hogy ezek mérési eredményei egyelöre még számos értékelésbeli kérdést vetnek fel) (AMÉZKETA et al., 2003.; BIEGANOWSKI et al., 2010). A mikroaggregátum meghatározási vizsgálatokról következö cikkünkben kívánunk részletes ismertetőt adni.

A talajok aggregátum-stabilitása meghatározható közvetett módon is, például a talajok folyadék-visszatartó, illetve folyadékvezető képességének vízben és apoláros folyadék közegben mért értékének összehasonlításával (HILLEL, 1998; RAJKAI et al., 2015; MAKÓ, 2018). Az aggregátum-stabilitás elörejelzése egy adott talajféleségre nézve végezhető becslő (pedotranszfer) függvényekkel történő számítás alapján is. A hagyományos regressziós modellek széles körü alkalmazása mellett a talaj aggregátum-stabilitásának becslésére az utóbbi időkben igen ígéreteseknek bizonyultak a különbözö mesterséges intelligencia rendszerek (AZAMATHULLA et al., 2009; BoCCO et al., 2010; JAKAB et al., 2019).

\section{A nedves szitás makroaggregátum-stabilitás vizsgálat hazai és külföldi elözményei}

A nedves szitálás (wet sieving) módszere a makroaggregátumok stabilitásának vizsgálatára szolgál a víz erodáló hatásával szemben (YODER, 1936; KEMPER \& KoCH, 1966). A talajmorzsák vízállósága adott időtartamú és intenzitású vizes kezelésnek kitett talajmorzsák stabilitását jelenti (VÁRALlYAY, 1993). Azt a tapasztalatot veszi alapul, hogy az aggregátumok kötőanyagainak bizonyos hányada vízben oldható, vagy mobilizálható, éppen ezért ezek a talaj nedvesedésével 
párhuzamosan kioldódnak. Más, vízben nem oldható anyagok kötőereje a nedvesítés hatására szintén csökkenhet (SIX et al., 2000).

A mérések alapja, hogy ismert tömegủ, valamilyen módszerrel előnedvesített talajmintát folyamatos vízáramban vagy állandó mennyiségủ vízben, eltérő (vagy csak egy meghatározott) lyukátmérőjü szitán vagy szitákon átszitálunk, elkülönítve ezzel a különböző mérettartományba sorolható aggregátum frakciókat. A nedves szitás módszer előnye, hogy a mérésből nyert adatok közvetlenül a vízálló talajaggregátumok százalékos mennyiségét adják meg, mely értékek elviekben azonos módszer esetén egymással is összehasonlíthatók (DVORACSEK, 1952).

A nedves szitás mérést először a legtöbb irodalom szerint TYULIN 1928-as tanulmányában említették (DI GLÉRIA et al., 1957; LAL \& SHUKLA, 2004). A gépi szitálás módszerét YODER (1936) dolgozta ki elsőként, majd a későbbiek során WILLIAMS és munkatársai (1966) fejlesztették ezt tovább. KEMPER és KOCH (1966) még ugyanebben az évben felismerte a szabványosítás szükségességét, majd innentől kezdve többségében ezen standard módositásait, tökéletesítéseit közölték az újabb aggregátum-stabilitás vizsgálatokról szóló irodalmak. Korábban ugyanis YODER (1936) módszerét alapul véve többszitás (szitasorozatos) módszereket alkalmaztak. KEMPER és ROSENAU (1986) arra a következtetésre jutottak, hogy az egyszitás módszerek alkalmazásával kapott eredmények gyakorlati szempontból ugyancsak jól közelítették a terepen tapasztaltakat, és szemben a többszitás módszerekkel, ezek kevésbé munka- és időigényesek, így az egyszitás módszer alkalmazása széleskörűen terjedni kezdett (BEARE \& BRUCE, 1993; AMÉZKETA, 1999).

Magyar vonatkozásban DVORACSEK 1950-ben, MARQUETANT 1952-ben, KLIMES-SZMIK és DI GLÉRIA 1957-ben, később BALLENGERREL közösen 1962-ben, foglalkoztak a nedves szitás módszer fejlesztésével. DVORACSEK 1950-ben hét darab, különbözö lyukbőségủ szitából álló szitasorozattal vizsgálta a talajok rögszerkezetét - amely az orosz SZAVVINOV-féle (1931) müszer módosítása volt. Ezt az eszközt egyszerüsítette MARQUETANT 1952-ben azzal, hogy csak az 1-3 mm közötti frakciót vizsgálta. A gépesítéssel a kézi szitálásból eredő szubjektív hibák kiküszöbölhetőek voltak (DVORACSEK, 1953). A sorozatvizsgálatokra való alkalmazhatósághoz további egyszerüsítéssel jutott KLIMES-SzMIK (1962). KRÁMER (1952) összehasonlított több talajmorzsa vízállékonysági módszert, és közel hasonló értékeket kapott, ugyanakkor felhívta figyelmet az előkezelés fontosságára különösen a kötött és a szikes talajok esetében. DVORACSEK és munkatársai (1953) a kötöttség befolyásoló hatását vizsgálták: a müvélés hatására nagyobb mértékben csökken a morzsavízállóság, mint arra a nagyobb kötöttségi számok alapján következtetni lehetne. MAJOR (1974) szoros összefüggést talált az aggregátumok vízzel szembeni ellenállása és a leiszapolható rész mennyisége között különböző talajtípusok esetében. A talaj típusa csak az adott talajon elérhető legnagyobb szerkezeti stabilitást adja meg, ám az aggregátumok tartóssága már nem csupán a talajtípustól függött, hanem pl. a szervesanyag mennyiségétől, minőségétől, a területhasználattól is (DVORACSEK, 1952). A morzsalékos állapot nem feltétlenül jelentette a talajszerkezet tartósságát, viszont az megállapítható volt, hogy minél kisebb a morzsa, annál vízállóbb (DVORACSEK, 1952). A vizsgálathoz használt víz hőmérséklete is befolyásolhatja az eredményeket: minél magasabb a víz 
A talajok aggregátum-stabilitásának vizsgálati lehetőségei I. Makroaggregátum-stabilitás 93

hőmérséklete, annál nagyobb a $0,25 \mathrm{~mm}$ alatti frakció mennyisége, és kisebb az $1 \mathrm{~mm}$-nél nagyobb aggregátumok stabilitása (BALLENEGGER, 1953; SEKIGUCHI et al., 2021).

\section{A makroaggregátum stabilitás vizsgálatát befolyásoló tényezők}

A különböző irodalmakban közöltek szerint a nedves szitás mérések eredményeit számos tényező befolyásolhatja, ilyen például a mintavétel, az elökészités, az elönedvesités, valamint a homokkorrekció.

A terepi mintavételezésre különösen nagy figyelmet kell fordítani, mivel az aggregátum-stabilitás mértéke évszakos változást mutat (MULLA et al., 1992; DUNAI \& TóTH, 2015). Célszerủ a mintákat az év azonos időszakában begyüjteni és kerülni a szélsőséges (pl. száraz, túlnedvesedett vagy fagyos) körülményeket. Fontos szerepe van a mintavételi eszközöknek és a minták tárolásának is. A mérésre szánt talajmintákat az összetöredezés megelőzése végett merev falú dobozokban kell a laboratóriumba szállítani, majd ezt követően azonnal meg kell kezdeni levegőn történő szárításukat (KEMPER \& ROSENAU, 1986; LE BISSONNAIS, 1996). A levegőn történő szárítás célja, hogy már a kezdeti lépésekben teljesüljenek a szabványosítás feltételei (AMÉzKETA, 1999). KEMPER és ROSENAU (1986) valamint MURER és munkatársai (1993) szerint az aggregátum-stabilitás a tárolás idejével arányosan lassan növekszik, ezért célszerü a vizsgálatokat a minták száradását követően azonnal elkezdeni. A minták hosszú távú tárolásához javasolt a fagyasztva-szárítást alkalmazni (JASTROW \& MILLER, 1991). A módszerek kisebb hányada a mintákat nedves állapotban (szántóföldi nedvesség állapotában) vizsgálja, és létezik olyan módszerleírás is, ahol nedves és száraz állapotú mintákkal is elvégzik a vizsgálatokat (KEMPER \& ROSENAU, 1986; OADES \& WATERs, 1991; ROBERSON et al., 1991; AMÉZKETA, 1999).

A minták méréshez történő előkészitésének első lépése a szitálás. Van olyan módszer is, ahol a mintákat nem frakcionálják a nedves szitás vizsgálat előtt, azonban legtöbben arra a megállapításra jutottak, hogy az eredmények jobban reprodukálhatóak, gyorsabbak és kisebb anyagigényủek, ha meghatározott mérettartományú aggregátumokkal történik a vizsgálat (KEMPER \& KOCH, 1966; KeMPER \& ROSENAU, 1986; KAY \& DeXTER, 1990). A mérettartománynak a megválasztása a módszertől függően változhat. A módszerekben alkalmazott előkészített, leszitált minták a 0,5-1 mm közti mérettartománytól az 5-8 mm közti mérethatárig terjedhetnek (AMÉZKETA, 1999). A legtöbb szabványosított mérési módszerben 1-2 mm átmérőjü mintákat alkalmaznak, (KEMPER \& KOCH, 1966; KEMPER \& RosenaU, 1986; DicKSON et al., 1991; BlanCO-MOURE et al., 2012). DVORACSEK 1950-ben a 1-3 mm közötti frakciót vizsgálta a Szavvinov-eljárás módosítása során. Akad olyan módszer, ahol a mérés csak a $2 \mathrm{~mm}$ alatti frakció vizsgálatára terjed ki (LOCH \& FOLEY, 1994). Más szerzők a 2-2,8 mm (CHANEY \& SwIFT, 1986), valamint a 2-4 mm (HAYNES \& SWIFT, 1990), és 3-4 mm (LE SOUDER et al., 1991), továbbá a specifikusan megállapított 3,35-5,60 mm közé szitált frakció vizsgálatát javasolták (MATKIN \& SMART, 1987). OADES és WATERS (1991) a 4 mm 
alatti frakció elkülönítését írta elö, míg BURKE és munkatársai (1986) az 1-8 mm közötti frakció vizsgálatát részesítették előnyben.

A minták előkészítésének másik fontos lépése az elönedvesités. $\mathrm{Az}$ elönedvesítési eljárásokra szintén számos gyakorlat létezik. A mintákat a legtöbb esetben desztillált vízzel nedvesítik. YODER (1936) módszerében az előnedvesítést vákuum nélkül, rövid időtartamban alkalmazta, KEMPER és KOCH (1966) erős vákuum mellett történő gyors nedvesítést alkalmazott. Találkozunk még a szakirodalomban a vákuum nélküli atmoszférikus nyomáson történő lassú, kapilláris nedvesítéssel, erős vákuum mellett történő lassú kapilláris nedvesítéssel, illetve párologtató készülék gőzterében történő kíméletes előnedvesítéssel (KEMPER \& RoSENAU, 1986). A gyors nedvesítések előnye, hogy jobban szimulálják az öntözés és a heves esőzések okozta szerkezetromboló hatást. A lassú kapilláris nedvesítéssel ezzel szemben inkább a csendes esőzések hatásait és talajvízből kapilláris úton történő benedvesítést modellezhetjük. Az előnedvesítési eljárások és az előnedvesített minta víztartalma nagyban meghatározzák a stabilitási mérések eredményeit. KEMPER és ROSENAU (1986) azt tanácsolta, hogy a könnyebb reprodukálhatóság érdekében, a talajmintákat a nedves szitálás előtt a szabadföldi vízkapacitás értékükig célszerủ előnedvesíteni. CAMBARDELLA és ELLIOTT (1993) az előkészített mintáknál (kapillárisan nedvesített), a szabadföldi vízkapacitás állapotát elérve további plusz $5 \mathrm{~m} / \mathrm{m} \%$ víztartalommal növelte a nedvességtartalmat, amelynek hatására a mérés során elérték a maximális legkedvezőbb stabilitási értéküket. SUN és munkatársai (1995) kimutatták, hogy a szitálást megelőzően a mintákon a nedvesítést telítésig elvégezve az adott talajnál a maximálisan elérhető aggregátum-stabilitási eredmények kaphatók. Az előnedvesítés egyéb folyadékokkal is történhet, mint például etanollal (HÉNIN et al., 1958; LE BISSONNAIS et al., 1989), víz-alkohol-benzol keverékkel (BURKE et al., 1986), $\mathrm{NaCl}$ vagy $\mathrm{NaIO}_{4}$ oldatokkal (ANGERS \& MEHUYS, 1989). A különböző nedvesítésekkel végzett vizsgálatok rendre kimutatták, hogy a legfontosabb destabilizáló tényező az előnedvesítés során az aggregátumokba szorult levegő volt. A gyors nedvesítések éppen ezért eltérő (kisebb stabilitási) eredményeket produkálnak (vákuum esetében mérsékeltebb ez a hatás), mint a lassú, fokozatos kapilláris úton történő nedvesítések, melyek kiküszöbölték az aggregátumokba szorult levegő hirtelen nyomásváltozásból adódó szétrobbantó hatását. Reprodukálhatóság és könnyebb elérhetőség szempontjából a vákuum alkalmazása helyett az atmoszférikus nyomáson történő lassú kapilláris nedvesítés a leginkább javasolt előnedvesítési eljárás (DICKSON et al., 1990). Az előnedvesítés szempontjából hatékonynak bizonyult, ha az előzetesen bemért légszáraz mintát közvetlen a szitákra helyezzük, majd a kapilláris nedvesítést a szita alá helyezett itatóspapíron keresztül valósítjuk meg legalább 5 perces időtartamban. Így kiküszöbölhetők azok mechanikai romboló hatásokból eredő hibák, melyek a benedvesített minta szitára helyezésből fakadhatnak (MAKÓ, 2018).

A nedves szitás mérések során az egyes módszerek a desztillált víz mellett különféle diszpergálószerek adagolását is javasolják (pl. Na-pirofoszfát, Na-hexametafoszfát és Na-karbonát oldatok) (TISDALL \& OADES, 1979), esetleg mechanikai diszpergálást alkalmaznak, például ultrahangozást (NORTH, 1976), vagy vízben végzett keverés egyéb módszereit (pl. POJASOK \& KAY, 1990; BEARE \& 
BRUCE, 1993). Egyes szerzők desztillált víz helyett ionmentes vizes közegben végezték a szitálást (STRICKLAND et al., 1988). Az aggregátum stabilitás apoláros szerves folyadékokban is vizsgálható, ebben az esetben a poláros vízmolekulák kémiai diszpergáló hatásával nem kell számolni, csak a mechanikai diszpergáló hatásokkal (MAKÓ, 2018).

Homok-korrekció azért szükséges, mivel a homoktartalom zavarja a makroaggregátum-stabilitás mérési eredményeit. A nedves szitálás során a vízálló aggregátumok tömegéhez ugyanis hozzáadódik a makroaggregátum méretủ homokfrakció (illetve a talajban előforduló egyéb szerves törmelék) is, ez pedig a vízálló aggregátumok arányának felülbecslését okozza. Éppen ezért korrigálni szükséges a homokfrakció tömegével a nedves szitálás eredményét, mégpedig a 0,25 mm-nél nagyobb aggregátumokkal azonos méretủ homok- és szerves törmelékfrakció tömegének kivonásával a vízstabil aggregátumok tömegéből (DI GLÉRIA et al., 1957; SIX et al., 2000). A jelenleg javasolt Eijkelkamp módszertan (2008) alapján nincs szükség homok korrekcióra abban az esetben, amikor nem a szitákon fennmaradt makroaggregátumok tömegét határozzuk meg, hanem első lépésben a vízben nem stabil aggregátumok, második lépésben a vízben stabil aggregátumok tömegét a sziták alatti szuszpenziók bepárlási maradékaiból.

A nedves szitás mérés során a szitálási folyamat ideje és merítés számok, valamint a szita függőleges kimozdulásának mértéke (amplitúdója) is módszertől függően változnak. A legtöbb mérési módszer általában 3 perc alatt történő 35 merítési ciklusból áll percenként, 1-3 centiméteres vertikális távolság megtételével. Más nedves szitás módszerek a 10 perces szitálást alkalmazzák, 40 merítési ciklus/perccel (POJASOK \& KAY, 1990), de 1 perces szitálásos 25 merítési ciklus/perc eljárás is létezik (HAYNES \& SWIFT, 1990).

Az alkalmazott módosított vizsgálatok alap-módszereinek túlnyomó többsége a YODER-féle (1936) többszitás, vagy a KEMPER és KOCH (1966), illetve KEMPER és ROSENAU-féle (1986) egyszitás vizsgálati eljárások valamelyike. Az egyszitás mérések előnye, hogy könnyebben összehasonlíthatóak más, hasonló egyszitás módszerekkel. A mérések korlátozott összehasonlíthatóságának fö oka általában az, hogy a számos létező módszer valamelyik lépésében eltér a többitől, vagy az előkészítési folyamatok nem azonosak.

Léteznek úgynevezett többlépcsős értékelésen alapuló összehasonlító módszerek is. A legismertebb mind közül LE BISSONNAIS 1996-ban publikált három eredményes összehasonlító módszere. LE BISSONAIS három kezelést alkalmazott a vizsgált 3-5 mm közötti frakciójú légszáraz talajmintákra. A mintákat közvetlenül a kezelés előtt 24 órán át $40{ }^{\circ} \mathrm{C}-\mathrm{os}$ szárítószekrénybe helyezte, hogy állandó mátrixpotenciált érjen el. A mintákat ezután kétféle előkezelésnek vetette alá. Az egyik esetben a száraz talajt közvetlenül egy ionmentesített vízzel töltött $(50 \mathrm{ml})$ főzőpohárba helyezte (gyors nedvesítés), a második típusú előkezelés a lassú kapilláris nedvesítés (szürőpapír segítségével), a harmadik esetben nem alkalmaz előkezelést a mintákon, hanem a vizsgálat további szakaszában száraz állapotban kezdi meg szitálásukat. Ezt követően a kétféleképpen előkezelt mintákat, valamint a szárazon hagyottakat $50 \mu \mathrm{m}$-es szitára helyezte, ahol azokat etil-alkoholba mertíve gépi szitálást végzett (5 ciklusban; 1 sec/ciklus) HÉNIN és munkatársai (1958) 
módszere alapján. Az etanol alkalmazása segít elkülöníteni az aggregátum-szétesés különbözö formáit, mint a mechanikai hatás, duzzadás, diszperzió (CONCARET, 1967; EMERSON \& GREENLAND, 1990; LE BisSONAIS, 1996). Ezután az 50 m-es szitán fennmaradt frakciót kiszárítást követően $\left(48\right.$ óra $40{ }^{\circ} \mathrm{C}$-on) egy szitasorozaton $(<0,25$ $\mathrm{mm}, 0,25-0,5 \mathrm{~mm}, 0,5-1 \mathrm{~mm}, 1-2 \mathrm{~mm}, 2-5 \mathrm{~mm}$ ) száraz állapotban óvatosan átszitálta. Az $50 \mu$ m-nél kisebb frakciót a kezdeti és a visszamért tömegek különbségeként kapjuk, és ezzel kiszámítható az egyes frakciók százalékos aránya a kezdeti tömeghez viszonyítva. Az egyes szitákon fennmaradt talajanyag mennyisége alapján fejezte ki és hasonlította össze az előkezelések eredményeit: meghatározta a szitálás utáni átlagos súlyozott átméröt (mean weighted diameter, MWD) és a sérülékenységi együtthatót (melyet a kapott átlagos súlyozott átmérő értékek segítségével számolt), valamint megállapította a vízben stabil aggregátumok százalékát.

\section{2. táblázat}

A nedves szitás módszerek változatainak összefoglalása

\begin{tabular}{|c|c|c|c|c|c|c|}
\hline \multirow{3}{*}{ 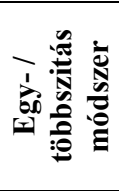 } & \multirow{3}{*}{$\begin{array}{c}\text { Szita lyuk- } \\
\text { átmérője }\end{array}$} & \begin{tabular}{|c|} 
Előkészített \\
minta \\
frakció \\
\end{tabular} & \multirow[t]{3}{*}{\begin{tabular}{|} 
Előnedvesítés \\
időtartama
\end{tabular}} & \multirow[t]{2}{*}{$\begin{array}{c}\text { Diszpergáló } \\
\text { közeg }\end{array}$} & $\begin{array}{l}\text { Merítések } \\
\text { száma }\end{array}$ & \multirow[t]{3}{*}{ Szerzők } \\
\hline & & mérete & & & Idötartama & \\
\hline & & tömege & & Diszpergáló-szer & Amplitúdó & \\
\hline \multirow{3}{*}{ 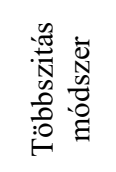 } & \multirow{3}{*}{ nem ismert } & teljes frakció & \multirow{3}{*}{$\begin{array}{c}\text { gyors } \\
\text { nedvesítés }\end{array}$} & desztillált víz & $\begin{array}{l}30 \text { merités } \\
\text { /perc }\end{array}$ & \multirow{3}{*}{ YODER, 1936} \\
\hline & & & & & 10 perc & \\
\hline & & $50 \mathrm{~g}$ talaj & & - & $A: 3,18 \mathrm{~cm}$ & \\
\hline \multirow{3}{*}{ 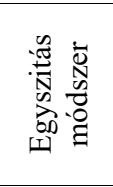 } & \multirow{3}{*}{$0,26 \mathrm{~mm}$} & $1-2 \mathrm{~mm}$ & \multirow{3}{*}{$\begin{array}{c}\text { gyors } \\
\text { nedvesítés, } \\
\text { vákuum alatt }\end{array}$} & desztillált víz & $\begin{array}{l}35 \text { merités } \\
\text { /perc }\end{array}$ & \multirow{3}{*}{$\begin{array}{c}\text { KEMPER \& } \\
\text { KOCH (1966) }\end{array}$} \\
\hline & & & & & 5 perc & \\
\hline & & - & & $\begin{array}{c}0,5 \% \text {-os Na- } \\
\text { hexametafoszfát }\end{array}$ & $A: 1,3 \mathrm{~cm}$ & \\
\hline \multirow{3}{*}{ 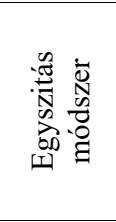 } & \multirow{3}{*}{$0,26 \mathrm{~mm}$} & $1-2 \mathrm{~mm}$ & \multirow{3}{*}{$\begin{array}{l}\text { vákuum nélküli, } \\
\text { lassú nedvesítés } \\
\text { aeroszol }\end{array}$} & desztillált víz & $\begin{array}{l}35 \text { merítés } \\
\text { /perc }\end{array}$ & \multirow{3}{*}{$\begin{array}{c}\text { KEMPER \& } \\
\text { ROSENAU } \\
(1986)\end{array}$} \\
\hline & & & & & $3-5$ perc & \\
\hline & & $\begin{array}{c}4 g \\
\text { légszáraz } \\
\text { talaj }\end{array}$ & & $\begin{array}{c}\text { Na- } \\
\text { hexametafoszfát } \\
/ \mathrm{NaOH}(\mathrm{pH}<7)\end{array}$ & $\mathrm{A}: 1,3 \mathrm{~cm}$ & \\
\hline \multirow{3}{*}{ 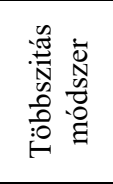 } & \multirow{3}{*}{$\begin{array}{c}4,75 ; 2 ; 1 ; \\
0,5 ; 0,425 ; \\
0,3 ; 0,208 ; \\
0,09 ; 0,053 \\
\mathrm{~mm}\end{array}$} & $5 \mathrm{~mm}>$ & \multirow{3}{*}{$\begin{array}{c}\text { lassú } \\
\text { előnedvesítés, } \\
\text { atmoszférikus } \\
\text { nyomáson } \\
\text { VKsz+5\% } \\
\end{array}$} & desztillált víz & $\begin{array}{l}50 \text { merités } \\
\text { /perc }\end{array}$ & \multirow{3}{*}{$\begin{array}{c}\text { ELLIOT } \\
(1986) \\
\text { SIX et al., } \\
(1999,2000)\end{array}$} \\
\hline & & $500 \mathrm{~g}$ & & & 2 perc & \\
\hline & & $\begin{array}{c}\text { légszáraz } \\
\text { talaj }\end{array}$ & & & $A: 3 \mathrm{~cm}$ & \\
\hline \multicolumn{7}{|c|}{ Több lépcsős értékelésen alapuló összehasonlító módszer } \\
\hline \multirow{3}{*}{ 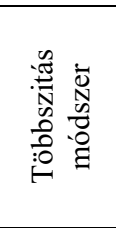 } & \multirow{3}{*}{$\begin{array}{l}2 ; 1 ; 0,5 \\
0,2 ; 0,1 \\
0,05 \mathrm{~mm}\end{array}$} & $3-5 \mathrm{~mm}$ & \multirow{3}{*}{\multicolumn{2}{|c|}{$\begin{array}{l}\text { 1. gyors nedvesítés }(10 \mathrm{~min}) \\
\text { 2. lassú nedvesítés }(60 \mathrm{~min}) \\
\text { 3. etanolos, majd vizes } \\
\text { nedvesítés }(30+30 \mathrm{~min})\end{array}$}} & 5 merítés & \multirow{3}{*}{$\begin{array}{c}\text { LE } \\
\text { BISSONNAIS } \\
(1996) \\
\text { ISO 10930 } \\
(2012)\end{array}$} \\
\hline & & & & & 1. etanolos & \\
\hline & & $\begin{array}{l}5-10 \mathrm{~g} 40 \\
C^{\circ} \text {-on } \\
\text { szárított } \\
\text { talaj } \\
\end{array}$ & & & $\begin{array}{l}\text { rázatás; } \\
\text { 2. száraz } \\
\text { szitálás } \\
\text { szitasoron }\end{array}$ & \\
\hline
\end{tabular}


A talajok aggregátum-stabilitásának vizsgálati lehetőségei I. Makroaggregátum-stabilitás 97

A módszerek sokfélesége (2. táblázat) egy idő után felvetette az egységesítés igényét, éppen ezért 2012-ben bevezetésre került a nedves szitálásos módszer nemzetközi szabványa (ISO 10930:2012). Ez a szabvány a HÉNNIN és munkatársai által 1958-ban publikált eljáráson alapszik. A módszer a mintaelőkészítéshez légszáraz minták 3-5 mm közé történő szitálását írja elö, melyet egy 24 órás $40{ }^{\circ} \mathrm{C}$-os szárítás követ. A szabvány az előnedvesítéssel kapcsolatban háromféle módon jár el: vízzel történő gyors nedvesítés és lassú kapilláris nedvesítés, illetve először etanollal, majd vízzel való nedvesítés. A szitálási folyamat is többlépcsős: etanolban történő nedves szitálás ( $50 \mu \mathrm{m}$-es szita), majd szárítás ( 48 óra $40{ }^{\circ} \mathrm{C}$-on), ezt követi egy száraz szitálási lépés $(2 ; 1 ; 0,5 ; 0,2 ; 0,1 ; 0,05$ mm-es szitasoron. A száraz szitálás után meghatározásra kerül az MWD értéke, melyet a 2 mm-nél nagyobb részecskék jelenléte esetében, ezek tömegét levonva korrigálnak (vázrészek korrekciója).

\section{Eredmények értékelése, kifejezése}

A nedves szitálásos módszer eredményeit legtöbbször kétféle módon, az aggregátumok mérete alapján, valamilyen módon súlyozva (VAN BAVEL, 1949) vagy vízben stabil aggregátumok százalékában fejezik ki (BARTLOVÁ et al., 2015).

A nedves szitálás eredményeit, az aggregátum stabilitását gyakran egy adott aggregátum méretosztály változása alapján mérik, amely mérés így nem a teljes talaj szerkezetének vizsgálatát foglalja magában. Célszerủ az eredményeket valamilyen egyesített mutatószámmal kifejezni, ilyenek az átlagos súlyozott átmérő (MWD), az átlagos geometriai átmérő (geometric mean diameter - GMD), a vízstabil (vízben stabil) makro-aggregátumok százaléka (water-stable aggregation - WSA), az aggregátum stabilitási index (aggregate stability index - ASI) (NIEWCZAS \& WITKOWSKA-WALCZAK, 2003), a normalizált stabilitási index (normalized stability index - NSI) (SIX et al., 2004) vagy a teljes talajstabilitási index (whole soil stability index - WSSI) (NICHOLS \& TORO, 2011).

$$
\operatorname{MWD}=\sum_{\mathrm{i}=1}^{\mathrm{n}} \mathrm{W}_{\mathrm{i}} \overline{\mathrm{x}}_{\mathrm{i}}
$$

ahol $n=$ frakciók száma, $x_{i}=$ az egyes frakciók átlagátméröje, $w_{i}=$ az egyes frakciókban elöforduló aggregátumok tömegaránya

Az MWD alkalmazását VAN BAVEL (1949) javasolta, azért, hogy az aggregátumokhoz olyan súlytényezőt rendeljenek, amely arányos a méretükkel, illetve hogy a teljes talajszerkezetet jellemző összes aggregátum frakciót egy számértékben egyesítse és fejezze ki (1. egyenlet). Az MWD mutatószámot gyakran a talajmüvelési módok hatásainak összehasonlítására alkalmazzák (HAYNES \& FRANCIS, 1993). Bővebb információval szolgálhat, ha összevetjük a száraz és a nedves szitálás utáni MWD értékeket (DE LEENHEER \& DE BOODT, 1967). Az MWD alkalmazása kérdéses lehet olyan esetekben, amikor az aggregátum frakciók nem követik a normál eloszlást (SIX et al., 2000; LU et al., 2016). Az MWD-vel szemben 
számos szerző inkább egyéb aggregátum stabilitási indexek használatát javasolja (CAÑASVERAS et al., 2010; TAVARES FILHO et al., 2012).

MAZURAK 1950-ben javasolta, hogy az átlagos geometriai átmérőt (GMD) (geometric mean diameter) használják az aggregátumok méret szerinti eloszlásának mutatójaként (2. egyenlet), illetve aggregátum-stabilitási mutatóként is. A GMD alkalmazását GARDNER (1956) megállapítása támasztja alá, mely szerint az aggregátumok méret szerinti eloszlása a legtöbb talajban megközelítőleg log-normál. Az aggregátum-stabilitás GMD értékben való kifejezését KEMPER és ROSENAU is alkalmazta 1986-ban publikált mérési módszerük eredmény-értékelése során.

$$
G M D=\exp \left(\frac{\sum_{i=1}^{n} W i \lg \overline{x l}}{\sum_{i=1}^{n} W i}\right)
$$

ahol $x_{i}=$ a szita lyukátméröje $(\mathrm{mm}) ; W_{i}=$ a teljes minta tömegének az $i$ méretü frakcióban elöforduló aránya; $n=$ a részecskefrakciók száma

A talajszerkezet nedves szitás értékelésének egyik legelterjedtebb módszere az aggregátumok vízzel szembeni stabilitásának (WSA) (water-stable aggregates) vizsgálata (3. egyenlet). Ez megadja, hogy az aggregátumok hány százaléka maradt stabil, azaz mutatott ellenállást a víz romboló hatásával szemben (KEMPER \& KOCH, 1966). A WSA eredményeket jelentősen befolyásolja a minta szervesanyag-, só- és agyagtartalma, valamint a nedves szitáláshoz végzett mintaelőkészítések (föként az elönedvesítés) (BARTLOVÁ et al., 2015).

$$
W S A_{i}=\frac{\left[W_{a}-W c\right]}{W_{0}} \times 100
$$

ahol $W_{S} A_{i}=$ vizstabil aggregátumok minden (i) méretosztályra; $W_{a}=a$ nedves szitálást követöen az i méretü szitán fennmaradt (száraz) anyag tömege $a$; $W_{c}=$ durva vázrész tömege i méretben; $W_{o}=$ a nedves szitálás elött az i méretü szitára helyezett aggregátumok abszolút száraz tömege

$\mathrm{Az}$ aggregátum-stabilitás mérések eredményeinek egyik kifejezője a szétrombolódási index (DI, disruption index) (VAN STEENBERGEN et al., 1991). Az aggregátumok romboló hatásra bekövetkezett tömegvesztése alapján kerül meghatározásra. Ennek végeredménye nem egy stabilitást kifejező érték, hanem azzal ellentétesen, a romboló erő által kifejtett hatást állapítja meg.

Szintén elterjedt a teljes talaj stabilitási index (WSSI) (whole soil stabilityindex) (NICHOLS \& TORO, 2011). Az eredmény kifejezhetösége érdekében a minták egy részét szárazon szitálták a $\mathrm{P}_{a i}$ (az összes i méretkategóriájú száraz-szitált aggregátumok aránya) meghatározása érdekében. Négy mérettartományban határozták meg a különbözö méretosztályokhoz tartozó aggregátumok tömegét, melyet azután arányosítottak a teljes tömegre vetítve. Ezután a nedves szitálást követően meghatározták az egyes méretosztályok WSA (vízstabil aggregátumok százaléka) értékét a KEMPER és RosENAU-féle 1986-os módosított módszerrel. A WSSI a száraz- $\left(\mathrm{P}_{a i}\right)$ és nedves szitás (WSA) indexek eredményeire épül 
A talajok aggregátum-stabilitásának vizsgálati lehetőségei I. Makroaggregátum-stabilitás 99

(4. egyenlet). Amennyiben értéke 0 , azt jelenti, hogy az összes aggregátum instabil, amennyiben értéke 1 az aggregátumok stabilitása $100 \%$.

$$
W S S I=\left[\frac{\sum_{i}^{n}\left[(I) \times(P a i) \times\left(\frac{W S A_{i}}{100}\right)\right]}{n}\right]
$$

ahol WSSI= teljes talaj stabilitási index; $n=$ az összesitett méretosztályok száma; $i=n$ értéke, mely 1-el csökken mindig a legnagyobb és a legkisebb aggregátum méretosztály között; $P_{a i}=a z$ egyes i tömegosztályok össztömegének aránya (száraz); WSA $A_{i}=$ vizstabil aggregáció minden i méretkategóriára vonatkozóan

A normalizált stabilitási index NSI (normalized stability index) egy az aggregáltsági indexből továbbfejlesztett mutató, melyet VAN STEENBERGEN és munkatársai dolgoztak ki 1991-ben. Az NSI méri a talaj aggregátum stabilitását, összehasonlítva az eredményeket az alkalmazott romboló hatás előtti és utáni állapotban. A NSI figyelembe veszi azt a tényt, hogy a különböző méretosztályba sorolható aggregátumok mennyiségi eloszlása nem normál eloszlású. Éppen ezért a rombolás mértékének kiszámításakor alkalmazott súlyozási tényező eltérő az egyes aggregátum-méretosztályokban, 1-4-ig közötti érték lehet (1 a legkisebb méretosztály esetében) (SIX et al., 2000).

NIEWCZAS és WITKOWSKA-WALCZAK 2003-ban publikált tanulmányukban egy új indexet alkalmaztak az ún. aggregátum-stabilitási indexet (ASI). A számítás egy szimplex algoritmus segítségével történik.

MÁRQUEZ és munkatársai 2004-ben publikálták a stabil aggregátumok aránya (SAI) (stable aggregates index) és a stabil makroaggregátumok aránya mutatókat (SMaI) (stable macroaggregates index) (5. és 6. egyenlet). A stabil aggregátumok mennyisége méröszámként használható a talaj stabilitásának számszerüsítésére és értékelésére. Tanulmányukkal rávilágítottak arra, hogy a KEMPER és KOCH által közölt 1966-os aggregátum stabilitás számítási módja (ahol gyors nedvesítést tekinti az előkészítés módjának) nem ad információt azon módszerekkel mért aggregátumstabilitásról, ahol az előnedvesítés kapilláris úton történik, éppen ezért számításaikban korrekciót alkalmaznak a gyors és a kapilláris nedvesítés romboló hatásai között. Ezek az indexek a stabil aggregátumok teljes súlyozott átlagát, illetve a stabil makroaggregátumok teljes súlyozott átlagát adják meg végeredményül. Számítási módszerük a korábbiakhoz képest nagyobb pontosságra törekszik, a számítás módja azonban többlépcsős.

$$
S A I=\frac{[(n+1)-j] S j}{[(n+1)-j] T j}
$$

ahol Sj= a stabil aggregátumok mennyisége a j frakcióban; Tj= az aggregátumok teljes mennyisége a j frakcióban (kapillárisan nedvesitett kezelésböl származó frakció), $n=a$ méretfrakciók teljes száma; $j=1$ a legnagyobb méretosztály esetén 
A SMaI a stabil makroaggregátumok mennyiségének súlyozott átlaga $(250 \mu \mathrm{m})$ és az összes aggregátum összesített súlyozott átlagának arányából számítható.

$$
S M a I=\frac{n \sum_{j=1}^{m}[(m+1)-j] S j}{m \sum_{j=1}^{n}[(n+1)-j] T j}
$$

ahol $\mathrm{Sj}$ = a stabil aggregátumok mennyisége a j frakcióban; $T j=$ az aggregátumok teljes mennyisége a j frakcióban (kapillárisan nedvesitett kezelésböl származó frakció), $n=a$ méretfrakciók teljes száma; $m=a>250 \mu m$-es méretosztályok teljes száma. $j=1 a$ legnagyobb méretosztály esetén

A közelmúltban, a talajszerkezet és az aggregátum méreteloszlás közötti kapcsolat jobb megértése érdekében a fraktálelmélet alkalmazása kezdett elterjedni (MARTINEZ-MENA et al., 1999; AHMADI et al., 2011). Néhány szerző specifikus fraktálparamétereket, például a fragmentált fraktálméretet $\left(F D_{n}\right)$ és a tömeges fraktálméretet $\left(F D_{m}\right)$ alkalmazta indikátorokként a növénytermesztés, a különbözö elönedvesítési kezelések és talajtulajdonságok vízstabil aggregátumok méreteloszlására gyakorolt hatásainak felmérésére (PERFECT \& KAY, 1995). A fraktál-geometria hasznos eszköz a talajfizikai tulajdonságok (pl. részecskék tömegarányának, pórusméret-eloszlásnak) skála szerinti kifejezésére is. Az úgynevezett D-érték (fraktáldimenzió) kiszámításával hasznos következtetések vonhatók le a talajok aggregátum-stabilitására vonatkozóan is (7. egyenlet) (SALAKO, 2006; WiLliams \& PetTiCREW, 2009).

$$
N>x=K(x)^{-D}
$$

ahol $N>x$ az x-nél nagyobb méretü aggregátumok összesitett száma; K állandó, mely függ a fragmentumok számától egy adott térfogati egységben. A D-értéket a log $N>x$ regressziójának meredekségéböl kapjuk, log $x$ - re feltételezve, hogy az aggregátumok kocka alakúak és sürüségük állandó

D értéke az aggregátumok esetében az aggregáltság mértékétől függ, ha D értéke abszolút értékben nagyobb, az nagyobb fokú aggregáltságot jelez (PERFECT \& KAY, 1991).

\section{Összefoglaló értékelés}

A makroaggregátumok stabilitásának meghatározására számos mérési módszer és értékelési lehetőség létezik. Ezek önállóan eredményesen alkalmazhatók az aggregátumok stabilitásának vizsgálatára (valamilyen romboló hatást megpróbálnak szimulálni, valamilyen körülményt megpróbálnak standardizálni stb.), ám ezek a módszerek egymással nehezen összevethetők. Az évek során jogosan merült fel a szabványosítás igénye, ám a kialakult nemzetközi szabvány módszertana igen bonyolult, éppen ezért csak kevesen kívánják azt alkalmazni. Hasonló a helyzet a különféle stabilitási mutatók esetében is: sokféle mutató használatos, ezek különkülön jól jellemezhetik a talajok aggregátum-stabilitását, de a mutatók párhuzamos 
A talajok aggregátum-stabilitásának vizsgálati lehetőségei I. Makroaggregátum-stabilitás 101

használata több esetben eltérő stabilitási sorrendet eredményez a különféle talajoknál. Megfelelő megoldás lehetne, ha definiálni tudnánk, hogy mely módszer és mely mutató pontosan mit is fejez ki és mikor, milyen probléma vizsgálatakor, mely mutatót és mely módszert kívánatos alkalmazni. Kutatásainkat a továbbiakban ilyen irányban is folytatni kívánjuk.

Kulcsszavak: makroaggregátum stabilitás, talajszerkezet, stabilitási index

\section{Köszönetnyilvánítás}

Kutatásunkat a Nemzeti Kutatási, Fejlesztési és Innovációs Hivatal (NKFIH) K119475 sz. pályázat, valamint az Innovációs és Technológiai Minisztérium ÚNKP20-3-II kódszámú Új Nemzeti Kiválóság Programjának a Nemzeti Kutatási, Fejlesztési és Innovációs Alapból finanszírozott szakmai támogatásával végeztük. Ezt a kutatást az Innovációs és Technológiai Minisztérium támogatta a Tématerületi Kiválósági Program 2020, Intézményi Kiválóság Alprogram (TKP2020-IKA-12) keretében a Szent István Egyetem vízzel kapcsolatos kutatásainak körében. Ezt a publikációt az EFOP-3.6.3-VEKOP-16-2017-00008 projekt támogatja. A projektet az Európai Unió és az Európai Szociális Alap társfinanszírozza.

\section{Irodalomjegyzék}

Ahmadi, A., Neyshabouri, M.R., Rouhipour, H. \& Asadi, H., 2011. Fractal dimension of soil aggregates as an index of soil erodibility. J Hydrol. 400. 305-311.

AmelunG, W., KaISER, K., KAMMERER, G. \& SAUER, G., 2002. Organic carbon at soil particle surfaces - evidence from x-ray photoelectron spectroscopy and surface abrasion. Soil Sci. Soc. Am. J. 66. 1526-1530.

AmÉZKETA, E., 1999. Soil aggregate stability: a review. J. Sustain. Agr. 14. (2-3) $83-151$.

AmÉZKeta, E., ARAgÜÉs, R., CARRANZA, R. \& URGEL, B., 2003. Macro- and microaggregate stability of soils determined by a combination of wet-sieving and laser-ray diffraction. Span. J. Agri. Res. 1. (4) 83-94.

ANGERS, D.A. \& MEHUYS, G.R., 1989. Effects of cropping on carbohydrate content and water-stable aggregation of a clay soil. Can. J. Soil Sci. 69. 373-380.

AZAmathulla, H.MD., Chang, C.K., GHANI, A.AB., ARIFFIn, J., ZAKARIA, N.A. \& ABU HASAN, Z., 2009. An ANFIS-based approach for predicting the bed load for moderately sized rivers. J. Hydro-Environ. Res. 3. (1) 35-44.

BALDOCK, J.A., \& KAY, B.D., 1987. Influence of cropping history and chemical treatments on the water-stable aggregation of a silt loam soil. Can. J. Soil Sci. 67. 501-511.

BALLENEGGER R., 1933. A rög fizikája. A Kis Akadémia Könyvtára. VII. kötet. Budapest.

BALLENEGGER R., 1953. Talajvizsgálati módszerkönyv. Mezőgazdasági Kiadó. Budapest. 
BALlANGeR R. \& DI GLÉRIA J., 1962. Talaj-és trágyavizsgálati módszerek. Mezőgazdasági Kiadó. Budapest.

Bartlová, J., BadalíKovÁ, B., Pospíšilová, L., PoKornÝ, E. \& ŠARAPATKa, B., 2015. Water stability of soil aggregates in different systems of tillage. Soil Wat. Res. 10. (3) 147-154.

Barzegar, A.R., Murray, R.S., Churchman, G.J. \& Rengasamy, P., 1994. The strength of remoulded soils as affected by exchangeable cations and dispersible clay. Aust. J. Soil Res. 32. (2) 185-199.

BEARE, M.H. \& BRUCE, R.R., 1993. A comparison of methods for measuring waterstable aggregates: implications for determining environmental effects on soil structure, Geoderma. 56. (1-4) 87-104.

BIEGANOWSKI, A., RYŻAK, M. \& WitOKOWSKA-WALCZAK, B., 2010. Determination of soil aggregate disintegration dynamics using laser diffraction. Clay Min. 45. $23-34$.

BLACKMAN, J.D., 1992. Seasonal variation in the aggregate stability of downland soils. Soil Use Manage. 8. (4) 142-150.

Blanco-Moure, N., Moret-Fernández, D. \& LóPez, M.V., 2012. Dynamics of aggregate destabilization by water in soils under long-term conservation tillage in semiarid Spain. Catena. 99. 34-41.

Bocco, M., Willington,E. \& ARIAs, M., 2010. Comparison of regression and neural networks models to estimate solar radiation. Chil. J. Agr. Res. 70. (3) $428-435$.

BRUCE-OKINE, E. \& LAL, R., 1975. Soil erodibility as determined by the raindrop technique. Soil Sci. 119. 149-157.

Burke, W., GABriEls, D. \& BoumA, J., (eds.). 1986. Soil structure assessment. Balkema Publisher, Rotterdam.

CAMBARDElla, C.A. \& ElliotT, E.T., 1993. Methods for separation and characterization of soil organic matter fractions. Geoderma. 56. 449-457.

CAÑASVERAS, J.C., BARRón, V., Del CAMPillo, M.C., Torrent, J. \& GómeZ, J.A., 2010. Estimation of aggregate stability indices in Mediterranean soils by diffuse reflectance spectroscopy. Geoderma. 158. 78-84.

Chaney, K., \& SwIFT, R.S., 1986. Studies an aggregate stability II. The effect of humic substances on the stability of reformed soil aggregates. J. Soil Sci. 37. 337-343.

Coleman, C.D., Callaham JR., M.A. \& Crossley Jr., D.A., 2018. Secondary Production: Activities of Heterotrophic Organisms - Microbes. In: Fundamentals of Soil Ecology ( $3^{\text {rd }}$ ed.). Academic Press. pp 47-76.

CONCARET, J., 1967. Etude des mécanismes de destruction des agrégats de terre au contact de solutions aqueuses. Ann. Agron. 18. 99-144.

De LeENHEeR, L. \& De BoODT, M., 1967. Aggregate stability determination by the change in mean weight diameter. In: DE BOODT, M. (Ed.) West-European Methods for Soil Structure Determination, West-European Working Group on Soil Structure of the International Soil Science Society. Gent, VI. pp 28-31.

DI GléRIA J., KLIMES-SzmiK A. \& DVORACSEK M., 1957. Talajfizika és talajkolloidika. Akadémiai Kiadó. Budapest. 
A talajok aggregátum-stabilitásának vizsgálati lehetőségei I. Makroaggregátum-stabilitás 103

Dickson, E.L., Rasiah, V. \& Groenevelt, P.H., 1991. Comparison of four prewetting techniques in wet aggregate stability determination. Can. J. Soil Sci. 71. 67-72.

DUNAI A. \& TóTH Z., 2015. Szerves- és mütrágyázás tartamhatása a talajaggregátumok stabilitására agyagbemosódásos barna erdőtalajon. Agrokem. Talajtan. 64. 29-52.

DVORACSEK M., 1950. A talaj rögszerkezetének vizsgálata. Agrártud. 2. 703-708.

DVORACSEK M., 1952. Adatok a talajszerkezet vízállóságának fiziko-kémiai alapjaihoz. In: Agrokémiai Kutató Intézet 1950-es évkönyve. Mezőgazdasági Kiadó. Budapest. 141-158.

DVORACSEKM., 1953. Hidrométeres súlymérés alkalmazása és egy gépesített megoldás a nedves szitálásos talajszerkezetvizsgálati módszerekhez. Agrokem. Talajtan. 2. 425-436.

DvoraCSEK M., KLIMES-SzMIK A. \& B. FEJÉR S. 1953. A kötöttség befolyása a talajmorzsák vízállóságára. Agrokem. Talajtan. 2. 17-26.

EIJKELKAMP, 2008. 08.13 Wet Sieving Apparatus Operation Instructions. Giesbeek, The Netherlands: Eijkelkamp

ElliotT, E.T., 1986. Aggregate structure and carbon, nitrogen, and phosphorus in native and cultivated soils. Soil Sci. Soc. Am. J. 50. 627-633.

EMERSON, W.W. \& GREENLAND, D.J., 1990. Soil aggregates-formation and stability. In: Soil colloids and their associations in aggregates (eds.: DE BOODT, M.F., Hayes, M.H.B. \& Herbillon, A.). Plenum Press, New York, N.Y., U.S.A. pp 485-511.

GARDNER, W.R., 1956. Representation of soil aggregate-size distributions by a logarithmic-normal distribution. Soil Sci. Soc. Am. Pro. 20. (15) 151-153.

HAYNES, R.J., \& FRANCIS, C.S., 1993. Changes in microbiological biomass C, soil carbohydrate composition and aggregate stability induced by growth of selected crop and forage species under field conditions. J. Soil Sci. 44. 665-675.

HAYNES, R.J. \& SWIFT, R.S., 1990. Stability of soil aggregates in relation to organic constituents and soil water content. J. Soil Sci. 41. 73-83.

Hbirkou, C., Martius, C., Khamzina, A., Lamers, J.P.A., Welp, G. \& AmelunG, W. 2011. Reducing topsoil salinity and raising carbonstocks through afforestation in Khorezm, Uzbekistan. J. Arid Environ. 75. (2) 146-155.

HÉNIN, S., MONNIER, G. \& COMBEAU, A., 1958. Methode pour l'étude de la stabilité structurale des sols. Ann. Agron. 9. (1) 71-90. (in French)

Hillel, D., 1998. Environmental soil physics. Academic Press. San Diego.

HuIsz, A. 2007. A talaj aggregátum-stabilitása az egységes aggregátum-stabilitási mutató tükrében. Acta Agr. Debr. Különszám. 26. 83-99.

ISO 10930: 2012. Soil quality - Measurement of the stabilty of soil aggregates subjected to the action of water. International Organization for Standarization, Geneva, Switzerland.

JAKAB, G., Dobos, E., MadarÁsz, B., Szalai, Z. \& SzABÓ, A.J., 2019: Spatial and temporal changes in infiltration and aggregate stability: A case study of a subhumid irrigated cropland. Water. 11.876.

JASTROW, J.D. \& MiLLER, R.M., 1991. Methods for assessing the effects of biota on soil structure. Agr. Ecosyst. Environ. 34. (1-4) 279-303. 
John, B., YAMASHITA, T., LUDWIG, B. \& FleSSA, H., 2005. Storage of organic carbon in aggregate and density fractions of silty soils under different types of land use. Geoderma. 128. (1-2) 63-79.

KACHINSKY, N.A., 1965. Soil physics. Kolos Publisher, Moscow. (in Russian)

KAY, B.D., 1997. Soil structure and organic carbon: a review. In: Soil processes and the carbon cycle (Eds.: Lal, R., Kimble, J.M., Follett, R.F. \& SteWART B.A.). CRC, Boca Raton, FL. pp 169-197.

KAY, B.D. \& DEXTER, A.R., 1990. Influence of aggregate diameter, surface area and antecedent water content on the dispersibility of clay. Can. J. Soil Sci. 70. (4) 655-671.

KeMPER, W.D. \& KoCH, E.J., 1966. Aggregate stability of soils from western United States and Canada. USDA-ARS Techn. Bull. 1355. Washington, DC.

KEMPER, W.D. \& ROSENAU, R.C. 1986. Aggregate stability and size distribution. In: Methods of soil analysis. Part 1. Physical and mineralogical methods (ed.: KLUTE, A.) $2^{\text {nd }}$ ed. Agronomy Monograph 9. ASA and SSSA, Madison, WI. 425-442.

KLIMES-SZMIK A., 1962. A talaj fizikai tulajdonságainak vizsgálata. In: BALLENEGGER R. \& Di GLÉRIA J. (szerk.): Talaj- és trágyavizsgálati módszerek. Mezőgazdasági Kiadó. 83-134.

KRÁMER M., 1952. Talajmorzsák vízállóságának vizsgálata. Agrokem. Talajtan. 1. 495-510.

LAL, R. \& SHUKLA, M.K., 2004. Principles of soil physics. Marcel Dekker, New York.

LE BissonnAIS, Y., 1988. Analysis of the mechanisms of disaggregation and the mobilisation of particles of soil under the action of rain. $\mathrm{PhD}$ thesis. University of Orléans, (in French)

LE BISSONNAIS, Y., 1996. Aggregate stability and assessment of soil crustability and erodibility: Theory and methodology. Eur J. Soil Sci. 47. (4) 425-437.

LE BiSSONNAIS, Y., BRUAND. A. \& JAMAGNE, M., 1989. Laboratory experimental study of soil crusting: relation between aggregates breakdown and crust structure. Catena. 16. 377-392.

LEHRSCH, G.A. \& JOLLEY, P.M., 1992. Temporal changes in wet aggregate stability. Transactions of the ASAE. 35. (2) 493-498.

Le SOUder, C., Le BisSONNAIS, Y. \& ROBERT, M., 1991. Influence of a mineral conditioner on the mechanisms of disaggregation and sealing of soil surface. Soil Sci. 152. 395-402.

Lobe, I., SANdhage-Hofmann, A., Brodowski, S., Du Preez, C.C. \& AmelunG, W., 2011. Aggregate dynamics and associated soilorganic matter contents as influenced by prolonged arable cropping in the South African Highveld. Geoderma. 162. (3-4) 251-259.

LOCH, R.J., \& FOLEY, J.L., 1994. Measurement of aggregate breakdown under rain: Comparison with tests of water stability and relationships with field measurements of infiltration. Aust. J. Soil Res. 32. 701-720. 
A talajok aggregátum-stabilitásának vizsgálati lehetőségei I. Makroaggregátum-stabilitás 105

LU, J., ZHENG, F., LI, G., BIAN, F. \& AN, J., 2016. The effects of raindrop impact and runoff detachment on hillslope soil erosion and soil aggregate loss in the Mollisol region of Northeast China. Soil Till. Res. 161. $79-85$.

MAJOR I., 1974. Aggregátum-minőségi elemzések felhasználása a talaj erodálhatósága megítélésében. Kísérl. Közl. Növényt. LXVI/A. 19-34.

MAKÓ A., 2018. Új talajfizikai mérö- és becslömódszerek kidolgozása vizes és nemvizes folyadékfázist tartalmazó talajokra. MTA doktori értékezés. Budapest.

MARQUETANT K., 1952. Gyors talajszerkezet vizsgálati módszer. Agrártud. 4. (2) 69-71.

Marshall, T.J. \& Holmes, J.W., 1979. Soil Physics. Cambridge University Press, Cambridge.

Martinez-MenA, M., DeEKS, L.K. \& Williams A.G., 1999. An evaluation of fragmentation fractal dimension technique to determine soil erodibility. Geoderma. 90. (1-2) 87-89.

MATKIN, E.A. \& SMART, P. 1987. A comparison of tests of soil structural stability. J. Soil Sci. 38. 123-135.

MAZURAK, A.P., 1950. Effect of gaseous phase on water-stable synthetic aggregates. Soil Sci. 69. (2) 135-148.

MCCALLA, T.M., 1944. Water drop method of determining stability of soil structure. Soil Sci. 58. (2) 117-123.

MEYER, L. \& VON RENNENKAMPFF, U., 1936. A new automatic apparatus for crumb analysis by Tinlin's method. Ztschr. Pflanz. Dung. 43. 268-280. (in German)

Mulla, D.J., HuYCK, L.M. \& REGANOLD, J.P., 1992. Temporal variation in aggregate stability on conventional and alternative farms. Soil Sci. Soc. Am. J. 56. 1620-1624.

Murer, E.J., Baumgarten, A., Eder, G., Gerzabek, M.H., Kandeler, E. \& RAMPAZZO, N., 1993. An improved sieving machine for estimation of soil aggregate stability (SAS). In: International Workshop on Methods of Research on Soil Structure/Soil biota Interrelationships (eds.: BRUSSAARD, L. \& KoOstra, M.J.). Geoderma. 56. 539-547.

MURRAY, R.S. \& QUIRK, J.P. 1990. Interparticle forces in relation to the stability of soil aggregates. In: Soil Colloids and their Associations in Aggregates (eds.: DE Boodt, M.F., Hayes, M.H.B., Herbillon, A., De Strooper, E.B.A., TuCK, J.J.). NATO ASI Series (Series B: Physics), vol 214. Springer, Boston, MA. pp 439-461.

NiCHOLS, K.A. \& TORO, M., 2011. A whole soil stability index (WSSI) for evaluating soil aggregation. Soil Till. Res. 111. (2) 99-104.

NIEWCZAS, J. \& WITKOWSKA-WALCZAK, B., 2003. Index of soil aggregate stability as linear function value of transition matrix elements. Soil Till. Res. 70. (2) 121-130.

NiEWCZAS, J. \& WiTKOWSKA-WALCZAK, B., 2003. Use of simplex algorithm for determination of soil aggregation extreme changes. Int. Agrophys. 17. 169-174.

NimMO, J.R., 2004, Aggregation: Physical Aspects. In:. Encyclopedia of Soils in the Environment (ed.: HiLleL, D.). Academic Press. London. pp 28-35.

NoRTH, P.F., 1976.Towards an absolute measurement of soil structural stability using ultrasound. J. Soil Sci. 27. (4) 451-459. 
OADES, J.M., 1990. Associations of colloids in soil aggregates, In: Soil Colloids and Their Associations in Aggregates (eds.: DE BOODT, M.F., HAYES, M.H.B. \& Herbillon, A.). NATO, AI Series, Series B: Physics Vol. 215, Plenum Press, Nw York. pp 463-483.

OADES, J.M., 1993. The role of biology in the formation, stabilization and degradation of soil structure. In: International Workshop on Methods of Research on Soil Structure/Soil biota Interrelationships (eds.: BRUSSAARD, L. \& KoOSTRA, M.J.). Geoderma. 56. 377-400.

OADES, J.M. \& WATERS, A.G., 1991. Aggregate hierarchy in soils. Aust. J. Soil Res. 29. (6) $815-828$.

Peng, X.H., Horn, R. \& Hallett, P., 2015. Soil structure and its functions in ecosystems: phase matter \& scale matter. Soil Till. Res. 146. 1-3.

PERFECT, E. \& KAY, B.D. 1991. Fractal theory applied to soil aggregation. Soil Sci. Soc. Am. J. 55. 1552-1558.

PERFECT, E. \& KAY, B.D., 1995. Applications of fractals in soil and tillage research: a review. Soil Till. Res. 36. (1-2) 1-20.

POJASOK, T., \& KAY, B.D., 1990. Assessment of a combination of wet sieving and turbidimetry to characterize the structural stability of moist aggregates. Can. J. Soil Sci. 70. (1) 33-42.

RAJKAi, K., Tóth, B., BARnA, G., HernÁdi, H., Kocsis, M. \& MAKÓ, A., 2015. Particle-size and organic matter effects on structure and water retention of soils. Biologia. 70. 1456-1461.

Roberson E.B., SARIG, S. \& Firestone, M.K., 1991. Cover crop management of polysaccharide-mediated aggregation in an orchard soil. Soil Sci. Soc. Am. J. 55. 734-739.

RoHoŠKovÁ, M. \& VALlA, M., 2004: Comparison of two methods for aggregate stability measurement - a review. Plant Soil Environ. 50. (8) 379-382.

SALAKO, F.K., 2006. Fractal scaling of soil particles in agricultural landscapes of Nigerian savannas. Int. Agrophys. 20. (4) 337-344.

SAVVINOV, N.I., 1931. Soil Structure and Its Stability. In: Virgin, Fallow, and Old Arable Lands (ed.: WILliams, V.R.). Sel'kolkhozgiz. Moscow. (in Russian)

SEKERA, F. \& BRUNNER, A., 1943. Beiträge zur Methodik der Gareforschung. Z. Pflanz. Bodenkunde. 29. 169-212.

SEKiguchi, R., SAITO, H., TANAKA,H. \& KOHGO, Y., 2021. Temperature dependence of volcanic ash soil aggregate stability: Effects of fertilizer application. Soil Till. Res. 207. 104870.

SiX, J., Bossuyt, H., DEgRYZE, S. \& DENEF, K., 2004. A history of research on the link between (micro)aggregates, soil biota, and soil organic matter dynamics. Soil Till. Res. 79. 7-31.

Six, J., Elliott, E.T. \& Paustian, K., 1999. Aggregate and soil organic matter dynamics under conventional and no-tillage systems. Soil Sci. Soc. Am. J. 63. 1350-1358.

SiX, J., ElLiOTT, E.T. \& PAUSTIAN, K., 2000. Soil structure and soil organic matter: II. A Normalized Stability Index and the effect of mineralogy. Soil Sci. Soc. Am. J. 64. 1042-1049. 
A talajok aggregátum-stabilitásának vizsgálati lehetőségei I. Makroaggregátum-stabilitás 107

Stefanovits P., FileP G. \& FÜleKY G., 1999. Talajtan. Mezőgazda Kiadó, Budapest.

Strickland, T.C., Sollins, P., Schimel, D.S. \& Kerle, E.A., 1988. Aggregation and aggregate stability in forest and range soils. Soil Sci. Soc. Am. J. 52. (3) 829-833.

SUllivAN, L.A., 1990. Soil organic matter, air encapsulation and water-stable aggregation. J. Soil Sci. 41. 529-534.

Sun, H., LARNEY, F.J. \& BullOCK, M.S., 1995. Soil amendments and water-stable aggregation of a desurfaced Dark Brown Chernozem. Can. J. Soil Sci. 75. 319-325.

Tavares-Filho, J., Feltran, C.T.M., DE Oliveira, J.F. \& DE AlmeidA, E., 2012. Modelling of soil penetration resistance for an Oxisol under no-tillage. Rev. Bras. Cienc. Solo. 36. (1) 89-95.

TISDALL, J.M., 1996. Formation of soil aggregates and accumulation of soil organic matter. In: Structure and Organic Matter Storage in Agricultural Soils (eds.: CARTER, M.R. \& Stewart, B.A.). CRC Press, Boca Raton, FL, USA. 57-96.

TisDALL, J.M. \& OADES, J.M., 1979. Stabilization of soil aggregates by the root systems of ryegrass. Aust. J. Soil Res. 17. 429-441.

TISDALL, J.M. \& OADES, J.M., 1982. Organic matter and water-stable aggregates in soils. J. Soil Sci. 33. (2) 141-163.

Totsche, K.U., Amelung, W., GerZabeK, M.H., Guggenberger, G., Klumpr, E., Knief, C., Lehndorff, E., Mikutta, R., Peth, S., Prechtel, A., Ray, N. \& KÖGEL-KNABNER, I., 2018. Microaggregates in soils. J. Plant Nutr. Soil Sc. 181. (1) 104-136.

Tyulin, A.F., 1928. Problems of Soil Structure. II. Aggregate Analysis as an Auxiliary Method for Assessing the Real Soil Structure.” In: Results of Works of the Agrochemical Department, Perm Experimental Station, on Flax (Perm) (in Russian).

VAGELER, P., 1932. Der Kationen- und Wasserhaushalt des Mineralbodens: Vom Standpunkt der Physikalischen Chemie und Seine Bedeutung für die Land- und Forstwirtschaftliche Praxis. Springer, Verlag Berlin Heidelberg.

VAN BAVEL, C.H.M., 1949. Mean weight diameter of soil aggregates as a statistical index of aggregation. Soil Sci. Soc. Am. Pro. 14. 20-23.

van Steenbergen, M., CAmbardella, C.A., Elliott, E.T. \& MerckX, R., 1991. Two simple indexes for distributions of soil components among size classes. Agr. Ecosyst. Environ. 34. (1-4) 335-340.

VÁrAllyay G., 1993. A talaj szerkezeti állapotának jellemzése. In: BUZÁs I. (szerk.): Talaj- és agrokémiai vizsgálati módszerkönyv 1. INDA 4231 Kiadó, Budapest. pp 71-82.

Williams, B.G., Greenland, D.J., Lindstrom, G.R. \& QUIRK, J.P., 1966. Techniques for the determination of the stability of soil aggregates. Soil Sci. 101. 157-163.

Williams, N.D. \& PetTiCREW, E.L., 2009. Aggregate stability in organically and conventionally farmed soils. Soil Use Manage. 25. (3) 284-292. 
YODER, R.E., 1936. A direct method of aggregate analysis of soils and a study of physical nature of erosion losses. J. Am. Soc. Agron. 28. 337-351.

\title{
Determination of soil aggregate stability I. Macro-aggregate stability
}

\author{
${ }^{1 *}$ Viktória LABANCz, ${ }^{2}$ Gyöngyi BARNA, ${ }^{1}$ Tamás SzEGI, ${ }^{2,3}$ András MAKÓ
}

${ }^{1}$ Szent István Campus, Hungarian University of Agriculture and Life Sciences, Gödöllö, Hungary; ${ }^{2}$ Institute for Soil Sciences, Centre for Agricultural Research, Budapest, Hungary; ${ }^{3}$ Georgikon Campus, Hungarian University of Agriculture and Life Sciences, Keszthely, Hungary

\section{Summary}

There are several measurement and evaluation methods for determining the stability of macro-aggregates. These can be used effectively independently to test the stability of aggregates (attempting to simulate some destructive effect, attempting to standardise some condition, etc.), but they are difficult to compare to each other. Over the years, the need for standardization has rightly arisen, but the standard method developed is very complicated, which is why few people want to apply it.

Similarly, many different indicators are used, each of which can give a good characterisation of the aggregate stability of soils, but the parallel use of indicators often results in different stability rankings for different soils. An appropriate solution should be defined which method and which indicator expresses what exactly and when, and which indicator and which method should be used for which problem. We intend to continue our research in this direction.

In this manuscript we summarized the main macro-aggregate stability measurements and indices, reviewed the international and Hungarian scientific literature.

Keywords: macroaggregate stability, soil structure, stability index

\section{Tables and figures}

Table 1.

Aggregate forming and stabilizing processes and materials

\begin{tabular}{|c|c|c|}
\hline Aggregates & Size & Forming and stabilizing processes and materilas \\
\hline Clay floccules & $<2 \mu \mathrm{m}$ & $\begin{array}{l}\text { Clay minerals coupling with intermolecular interactions (van der } \\
\text { Waals, electrostatic) }\end{array}$ \\
\hline $\begin{array}{l}\text { Clay floccules }+ \\
\text { silt grains }\end{array}$ & $\begin{array}{c}2-20 \\
(50,63) \mu \mathrm{m}\end{array}$ & $\begin{array}{l}\text { Coupling of clay-silt particles with colloidal size: iron-aluminium } \\
\text { oxides, organic matter, microbial activity }\end{array}$ \\
\hline Microaggregate & $\begin{array}{l}20(50,63)- \\
250 \mu \mathrm{m}\end{array}$ & Organomineral-complexes, bacterial activity, fungi hyphae \\
\hline Macroaggregate & $>250 \mu \mathrm{m}$ & $\begin{array}{l}\text { Fungal activity (e.g. fungi hyphae), plant roots and debris, organic } \\
\text { materials, effects of wetting-drying, and freezing-thawing cycles, } \\
\text { management (e.g. compost, manure) }\end{array}$ \\
\hline
\end{tabular}


A talajok aggregátum-stabilitásának vizsgálati lehetőségei I. Makroaggregátum-stabilitás 109

Table 2.

Summary of variations of wet sieving methods

\begin{tabular}{|c|c|c|c|c|c|c|}
\hline \multirow{3}{*}{$\begin{array}{c}\text { Single } \\
\text { sieve/Set of } \\
\text { sieves } \\
\text { method }\end{array}$} & \multirow{3}{*}{$\begin{array}{l}\text { Diameter of } \\
\text { sieve hole }\end{array}$} & $\begin{array}{l}\text { Prepared } \\
\text { sample } \\
\text { fraction }\end{array}$ & \multirow{3}{*}{$\begin{array}{l}\text { Duration of } \\
\text { wetting }\end{array}$} & \multirow[t]{2}{*}{$\begin{array}{l}\text { Dispersing } \\
\text { media }\end{array}$} & $\begin{array}{c}\text { Sieving } \\
\text { frequency }\end{array}$ & \multirow{3}{*}{ Reference } \\
\hline & & size & & & Duration & \\
\hline & & weight & & $\begin{array}{c}\text { Dispersing } \\
\text { agent }\end{array}$ & Amplitude (A) & \\
\hline \multirow{3}{*}{$\begin{array}{l}\text { Set of sieves } \\
\text { method }\end{array}$} & \multirow{3}{*}{ unknown } & whole fraction & \multirow{3}{*}{ fast wetting } & distilled water & $\begin{array}{c}30 \text { immersion } \\
\mathrm{Imin}\end{array}$ & \multirow{3}{*}{ Yoder, 1936} \\
\hline & & & & & $10 \mathrm{~min}$ & \\
\hline & & $50 \mathrm{~g}$ soil & & - & $A: 3,18 \mathrm{~cm}$ & \\
\hline \multirow{3}{*}{$\begin{array}{l}\text { Single sieve } \\
\text { method }\end{array}$} & \multirow{3}{*}{$0,26 \mathrm{~mm}$} & \multirow[t]{2}{*}{$1-2 \mathrm{~mm}$} & \multirow{3}{*}{$\begin{array}{l}\text { fast wetting, } \\
\text { under vacuum }\end{array}$} & distilled water & $\begin{array}{c}35 \text { immersion } \\
/ \mathrm{min}\end{array}$ & \multirow{3}{*}{$\begin{array}{l}\text { KEMPER \& } \\
\text { KOCH (1966) }\end{array}$} \\
\hline & & & & & $5 \mathrm{~min}$ & \\
\hline & & - & & $\begin{array}{l}0,5 \% \text { Na-hexa- } \\
\text { metaphosphate }\end{array}$ & $A: 1,3 \mathrm{~cm}$ & \\
\hline \multirow{3}{*}{$\begin{array}{l}\text { Single sieve } \\
\text { method }\end{array}$} & \multirow{3}{*}{$0,26 \mathrm{~mm}$} & $1-2 \mathrm{~mm}$ & slow wetting, & distilled water & $\begin{array}{c}35 \text { immersion } \\
1 \mathrm{~min}\end{array}$ & \multirow{3}{*}{$\begin{array}{c}\text { KEMPER \& } \\
\text { ROSENAU } \\
(1986)\end{array}$} \\
\hline & & & without vacuum, & & $3-5 \mathrm{~min}$ & \\
\hline & & $\begin{array}{c}4 \text { g air-dry } \\
\text { soil }\end{array}$ & aerosol & $\begin{array}{c}\text { Na-hexa- } \\
\text { metaphosphate/ } \\
\mathrm{NaOH}(\mathrm{pH}<7)\end{array}$ & $A: 1,3 \mathrm{~cm}$ & \\
\hline \multirow{3}{*}{$\begin{array}{l}\text { Set of sieves } \\
\text { method }\end{array}$} & \multirow{3}{*}{$\begin{array}{l}4,75 ; 2 ; 1 ; \\
0,5 ; 0,425 \\
0,3 ; 0,208 ; \\
0,090 ; 0,053 \\
\quad m m \\
m\end{array}$} & $<5 \mathrm{~mm}$ & \multirow{3}{*}{$\begin{array}{l}\text { slow wetting, } \\
\text { under } \\
\text { atmospheric } \\
\text { pressure, field } \\
\text { capacity }+5 \% \\
\end{array}$} & distilled water & $\begin{array}{c}50 \text { immersion } \\
/ \mathrm{min}\end{array}$ & \multirow{3}{*}{$\begin{array}{l}\text { ELLIOT (1986) } \\
\text { SIX et al., } \\
(1999,2000)\end{array}$} \\
\hline & & \multirow{2}{*}{$\begin{array}{c}500 \text { g air-dry } \\
\text { soil }\end{array}$} & & \multirow[b]{2}{*}{ - } & $2 \min$ & \\
\hline & & & & & $A: 3 \mathrm{~cm}$ & \\
\hline \multicolumn{7}{|c|}{ Method based on a multi-step evaluation } \\
\hline \multirow[b]{2}{*}{$\begin{array}{l}\text { Set of sieves } \\
\text { method }\end{array}$} & \multirow[b]{2}{*}{$\begin{array}{r}2 ; 1 ; 0,5 ; 0,2 ; \\
0,1 ; 0,05 \mathrm{~mm}\end{array}$} & $3-5 \mathrm{~mm}$ & \multirow{2}{*}{\multicolumn{2}{|c|}{$\begin{array}{l}\text { 1. fast wetting }(10 \mathrm{~min}) \\
\text { 2. slow wetting }(60 \mathrm{~min}) \\
\text { 3. wetting with ethanol, then } \\
\text { with dist. water }(30+30 \mathrm{~min})\end{array}$}} & 5 immersion & \multirow[b]{2}{*}{$\begin{array}{c}\text { LE } \\
\text { BISSONNAIS } \\
(1996) \\
\text { ISO 10930 } \\
(2012)\end{array}$} \\
\hline & & $\begin{array}{l}5-10 \mathrm{~g} \text { sample } \\
\text { dried at } 40 \mathrm{C}^{\circ}\end{array}$ & & & $\begin{array}{l}\text { 1. wet } \\
\text { sieving in } \\
\text { ethanol; } \\
\text { 2. dry sieving } \\
\text { with set of } \\
\text { sieves }\end{array}$ & \\
\hline
\end{tabular}

Open Access nyilatkozat: A cikk a Creative Commons Attribution 4.0 International License (https://creativecommons.org/licenses/by/4.0) feltételei szerint publikált Open Access közlemény, melynek szellemében a cikk bármilyen médiumban szabadon felhasználható, megosztható és újraközölhető, feltéve, hogy az eredeti szerző és a közlés helye, illetve a CC License linkje és az esetlegesen végrehajtott módosítások feltüntetésre kerülnek. (SID_1) 